\title{
Aktivitas Ekstrak Daun Kemuning (Murraya paniculata (L.) Jack) sebagai Hepatoprotektor pada Tikus yang Terpapar Asap Rokok
}

\section{The Activity of Kemuning Leaves Extract (Murraya paniculata (L.) Jack) as Hepatoprotector of Rats Exposed By Cigarette Smoke}

Ani Pahriyani ${ }^{1 *}$, Hadi Sunaryo², Desti Kurnia ${ }^{3}$

${ }^{1}$ FFS UHAMKA, Jakarta Timur, DKI Jakarta, Indonesia anipahriyani@uhamka.ac.id

\begin{abstract}
ABSTRAK
Rokok merupakan sumber radikal bebas yang dapat menyebabkan stress oksidatif dan dapat merusak fungsi organ-organ penting dalam tubuh diantaranya organ hati yang ditandai dengan peningkatan kadar SGPT dan SGOT. Penelitian bertujuan mengetahui aktivitas ekstrak etanol $70 \%$ daun kemuning (Murraya paniculata (L.) Jack) terhadap penurunan kadar SGPT dan SGOT pada tikus yang dipapar asap rokok.

Penelitian ini bersifat eksperimental menggunakan 25 tikus yang dibagi menjadi 5 kelompok yaitu kontrol normal(Ko), kontrol negative(Kn), dan 3 kelompok perlakuan yang diberi ekstrak etanol 70\% daun kemuning dengan dosis $100 \mathrm{mg} / \mathrm{KgBB}$ (K1), $200 \mathrm{mg} / \mathrm{KgBB}$ (K2), dan $400 \mathrm{mg} / \mathrm{KgBB}$ (K3). Data kadar SGPT dan SGOT dianalisis dengan ANOVA satu arah dan uji Tukey.

Hasil ANOVA satu arah menunjukkan terdapat pengaruh perlakuan terhadap kontrol ( $p$ $<0,05)$. Hasil uji Tukey dapat dilihat bahwa kadar SGPT pada dosis II dan III berbeda bermakna dengan kontrol negatif dan tidak berbeda bermakna dengan kontrol normal dengan hasil kadar sebesar 34,6 U/L (dosis II) dan 14,4 U/L (dosis III). Pada kadar SGOT semua kelompok perlakuan menunjukkan hasil berbeda bermakna dengan kontrol negatif dan tidak berbeda bermakna dengan kontrol normal dengan nilai sebesar 193,6 U/L (dosis I), 191,4 U/L (dosis II), 156,6 U/L (dosis III). Dari hasil penelitian dapat disimpulkan bahwa ekstrak etanol $70 \%$ daun kemuning memiliki aktivitas sebagai hepatoprotektor.
\end{abstract}

Kata kunci : asap rokok, ekstrak kemuning, Murraya paniculata (L.) Jack), SGOT dan SGPT

\section{ABSTRACT}

Cigarettes is a source of free radicals that can cause oxidative stress. It can cause functional failure of vital organs in the body including the liver that indicated by SGPT and SGOT increment. This research was aimed to observe the activity of $70 \%$ ethanol extract of kemuning leaves (Murraya paniculata (L.) Jack) on SGPT and SGOT digression of male white rats exposed by cigarette smoke.

This research was performed using 25 rats that were divided into 5 groups: normal control (Ko), negative control (Kn), and 3 treatment groups that were given $70 \%$ ethanol extract of kemuning leaves with $100 \mathrm{mg} / \mathrm{KgBW}$ (K1), $200 \mathrm{mg} / \mathrm{KgBW}$ (K2), and $400 \mathrm{mg} / \mathrm{KgBW}$ (K3). The SGPT and SGOT levels were analyzed by one-way ANOVA and Tukey test.

One-way ANOVA results showed there was a treatment effect on controls $(p<0.05)$. The results of the Tukey showed that the SGPT levels in doses II and III were significantly different from the negative controls but did not differ significantly from the normal controls with level value of $34.6 \mathrm{U} / \mathrm{L}$ (dose II) and $14.4 \mathrm{U} / \mathrm{L}$ (dose III). At SGOT levels all treatment groups showed significantly different comparing to negative controls and not significantly different to normal controls with level value of 193.6 U / L (dose I), $191.4 \mathrm{U} / \mathrm{L}$ (dose II), $156.6 \mathrm{U} / \mathrm{L} \mathrm{L}$ (dose III). It can be concluded that $70 \%$ ethanol extract of kemuning leaves has activity as a hepatoprotector

Keywords: ciggarete smoke, kemuning extract, Murraya paniculata (L.) Jack), SGOT dan SGPT 


\section{PENDAHULUAN}

Rokok merupakan hasil olahan tembakau terbungkus cerutu atau bentuk lain yang dihasilkan dari tanaman Nicotianatabacum, Nicotiana rustica, dan spesies lain atau sintesisnya yang mengandung nikotin dan tar dengan atau tanpa tambahan lainnya (Kemenkes RI 2010). Masalah yang ditimbulkan rokok belum bisa tertangani secara optimal hingga saat ini. Jumlah perokok di seluruh dunia terus mengalami peningkatan dari tahun ke tahun. Data dari GATS tahun 2011 menyebutkan bahwa Indonesia merupakan negara ketiga dengan jumlah perokok tertinggi di dunia setelah Cina dan India dengan prevalensi perokok sebanyak $36,1 \%$ (Sudibyo et al. 2013). WHO memperkirakan separuh kematian di Asia dikarenakan tingginya peningkatan penggunaan tembakau. Angka kematian akibat rokok di negara berkembang meningkat hampir 4 kali lipat. Pada tahun 2000 jumlah kematian akibat rokok sebesar 2,1 juta dan pada tahun 2030 diperkirakan menjadi 6,4 juta jiwa. Sedangkan di negara maju kematian akibat rokok justru mengalami penurunan, yaitu dari 2,8 juta pada tahun 2000 menjadi 1,6 juta jiwa pada tahun 2030 (Sudibyo et al. 2013).

Telah diketahui bahwa sebatang rokok memiliki berbagai macam bahan kimia yang terkandung di dalamnya. Apabila rokok tersebut dibakar, akan menghasilkan sekitar 4.800 jenis senyawa bahan kimia, di antaranya adalah nikotin, hydrogen cyanide, gas karbon monoksida, akrolein, nitrogen oksida, tar, ammonia, benzene, dan etanol. Beberapa kandungan rokok tersebut dapat memberikan dampak buruk terhadap kesehatan (Unitly et al. 2014). Tar merupakan salah satu sumber radikal bebas, karena tar mengandung ion besi, semiquinol dan hidroquinol. Ketiga bahan tersebut akan menghasilkan radikal peroksil dan hidrogen peroxida. Jika radikal bebas masuk ke dalam tubuh secara terus menerus akan membahayakan bagi kesehatan, dikarenakan sel tubuh akan mengalami stres oksidatif dan pada akhirnya sel akan mengalami kerusakan tak terkecuali sel hati (Muliartha 2009).

Organ hati sangat rentan terhadap kerusakan yang disebabkan oleh asap rokok yang bisa memicu terjadinya stres oksidatif. Sebagai organ yang berfungsi untuk melakukan detoksifikasi hati menghasilkan enzim yang dapat digunakan sebagai parameter kerusakan hati. Dua macam enzim aminotransferase tersebut adalah Serum Glutamic-Oxaloacetic Transaminase (SGOT) dan Serum Glutamic Pyruvic Transaminase(SGPT) (Apreliantino et al. 2012).

Penelitian Gautam et al. (2012) melaporkan bahwa ekstrak daun kemuning yang diuji secara in vivo memiliki antioksidan melalui peningkatan kadar GSH (Glutathione Peroxides). Pemberian dosis oral 100 $\mathrm{mg} / \mathrm{kgBB}$ menghasilkan kadar $\mathrm{GSH}$ $1,50 \mathrm{mmol} / \mathrm{g}$ dan dosis $400 \mathrm{mg} / \mathrm{kgBB}$ menghasilkan kadar GSH sebesar 2,15 $\mathrm{mmol} / \mathrm{g}$. Selain itu, pada penelitian secara in vitro diperoleh hasil, bahwa ekstrak etanol daun kemuning mempunyai nilai IC50 sebesar 126,17 $\mu \mathrm{g} / \mathrm{ml}$. Daya antioksidan daun kemuning kemungkinan ditimbulkan 
oleh karena adanya kandungan flavonoidnya (Rohman 2005).

Penelitian ini bertujuan untuk mengetahui pengaruh pemberian ekstrak etanol daun kemuning terhadap kadar SGPT dan SGOT tikus putih jantan yang dipapar asap rokok.

\section{METODE PENELITIAN}

Alat dan Bahan penelitian

Peralatan yang digunakan ialah vaccum rotary evaporator, spektofometri klinacal varta, centrifuge, smoking chamber.Bahan yang digunakan yaitu: daun kemuning (Murraya paniculata (L.) Jack) yang diperoleh dari Balitro, etanol $70 \%$, serum darah tikus, reagen kit SGPT dan SGOT, rokok kretek tanpa filter.

\section{Pembuatan ekstrak}

Simplisia yang telah diserbuk di maserasi dengan cara dimasukkan ke dalam botol berwarna gelap, maserasi dilakukan dengan cara menuangkan etanol $70 \%$ sampai seluruh serbuk terendam dan pelarut dilebihkan setinggi kurang lebih $2 \mathrm{~cm}$ di atas permukaan serbuk simplisia dan didiamkan selama 3 hari sambil sesekali diaduk agar senyawa-senyawa yang terkandung di dalam daun dapat lebih larut. Setelah itu disaring, maserat yang diperoleh disimpan sebagai maserat 1 . Selanjutnya ampas diberi perlakuan yang sama seperti maserat 1 hingga diperoleh maserat 2 dan maserat 3. Ketiga maserat kemudian dicampur dan pelarut diuapkan dengan vacum rotary evaporator pada tekanan rendah dan suhu tidak lebih dari $50^{\circ} \mathrm{C}$ hingga diperoleh ekstrak kental dan pekat tetapi masih dapat mengalir.
Selanjutnya dikeringkan dalam oven pada suhu $40^{\circ} \mathrm{C}$ selama 7 hari sehingga diperoleh ekstrak kering (Depkes R1 2008).

\section{Uji penapisan fitokimia}

Uji penapisan fitokimia yang diujikan pada ekstrak etanol $70 \%$ daun kemuning, yaitu senyawa alkaloid, flavonoid, saponin, triterpenoid dan tanin.

\section{Pemeriksaan mutu ekstrak \\ Pemeriksaan mutu ekstrak etanol $70 \%$ daun kemuning meliputi penetapan kadar abu, susut pengeringan, dan perhitungan rendemen.}

\section{Pemaparan asap rokok}

Rokok yang digunakan adalah rokok kretek tanpa filter. Tikus diberi paparan asap rokok 2 kali dalam sehari dalam waktu 10 menit. Proses paparan dilakukan pada pagi dan sore hari. Pemaparan dilakukan selama 14 hari. 30 menit setelah paparan tikus diberi ekstrak etanol daun kemuning peroral sesuai kelompok dosis dan berat badan tikus yang dilakukan pada sore hari atau pemaparan kedua. Pemaparan asap rokok menggunakan alat modifikasi smoking, dimana menggunakan spuit $50 \mathrm{cc}$ kemudian ujungnya diberi yellow tip, lalu siapkan selang plastik sesuai dengan ukuran rokok dan pasangan di dalam kandang khusus pengasapan, kemudian asap rokok disedot menggunakan spuit yang ujungnya dipasangkan dengan yellow tip. Asap rokok kemudian ditransferkan ke dalam kandang khusus pengasapan hewan coba. Hal tersebut dilakukan sampai rokok habis \pm 5 menit. 
Perlakuan hewan percobaan

Penelitian ini dibagi menjadi 5 kelompok, masing-masing kelompok terdiri dari 5 ekor tikus dan pemaparan asap rokok dilakukan selama 14 hari.

1. Kontrol normal yaitu kelompok tikus tanpa perlakuan

2. Kontrol negatif yaitu kelompok tikus yang dipapari asap rokok tanpa pemberian ekstrak etanol $70 \%$ daun kemuning

3. Kelompok perlakuan dosis I yaitu kelompok tikus yang dipapari asap rokok dan diberi ekstrak daun kemuning sebanyak $100 \mathrm{mg} / \mathrm{KgBB}$ selama 14 hari

4. Kelompok perlakuan dosis II yaitu kelompok tikus yang dipapari asap rokok dan diberi ekstrak daun kemuning sebanyak $200 \mathrm{mg} / \mathrm{KgBB}$ selama 14 hari.

5. Kelompok perlakuan dosis III yaitu kelompok tikus yang dipapari asap rokok dan diberi ekstrak daun kemuning sebanyak $400 \mathrm{mg} / \mathrm{KgBB}$ selama 14 hari.

Pengambilan sampel darah

Pada hari ke-15 semua hewan percobaan dibius menggunakan ketamin lalu dibedah, dan dilakukan pengambilan darah pada organ jantung tikus. Pengambilan darah pada jantung menggunakan spuit. Sampel darah dimasukan ke dalam tabung reaksi tanpa antikoagulan untuk mendapatkan serumnya. Tabung reaksi yang berisi darah tanpa antikoagulan didiamkan selama 60 menit pada suhu kamar. Kemudian disentrifugasi dengan kecepatan 1500 rpm selam 15 menit. Cairan bening di atas sel darah yang menggumpal selanjutnya diambil dengan pipet mikro dan dimasukan ke dalam tabung ependorf. Kemudian dilakukan pengukuran kadar SGOT dan $S G P T$ dengan menggunakan reagen Kit.

\section{Analisis data}

Data yang diperoleh dianalisis terlebih dahulu dengan uji prasyarat, yaitu uji Normalitas Kolmograv-Smimov (K-S) dan uji homogenitas Levene. Bila data homogen dan terdistribusi normal maka dilanjutkan dengan uji analisa varian (ANAVA) satu arah pada taraf kepercayaan $(a=0,05)$. Bila nilai sig $<0,05$ maka dilanjutkan dengan uji perbandingan berganda (Tukey).

HASIL DAN PEMBAHASAN

Pembuatan ekstrak etanol $70 \%$ daun kemuning

Tabel 1. Hasil ekstrak etanol $70 \%$ daun kemuning

\begin{tabular}{lll}
\hline No & Jenis & Hasil \\
\hline 1 & Daun kemuning segar & $5 \mathrm{~kg}$ \\
2 & Daun kemuning kering & $2,5 \mathrm{~kg}$ \\
3 & Serbuk kering & $1 \mathrm{~kg}$ \\
4 & Ekstrak kental etanol $70 \%$ daun & $156,246 \mathrm{~g}$ \\
& kemuning
\end{tabular}




\section{Pemeriksaan Karakteristik Ekstrak}

Tabel 2. Hasil Rendemen, Kadar Abu Total, dan Susut Pengeringan

Ekstrak Etanol 70\% Daun Kemuning

\begin{tabular}{lll}
\hline No & Jenis Uji & Hasil (\%) \\
\hline $\mathbf{1}$ & Rendemen Ekstrak & 15,62 \\
$\mathbf{2}$ & Kadar Abu Total & 5,87 \\
$\mathbf{3}$ & Susut Pengeringan & 4,03 \\
\hline
\end{tabular}

Uji penapisan fitokimia

Tabel 3. Penapisan Fitokimia Ekstrak Etanol 70\% Daun Kemuning

\begin{tabular}{lll}
\hline No & Penapisan & Hasil \\
\hline $\mathbf{1}$ & Alkaloid & + \\
$\mathbf{2}$ & Saponin & + \\
$\mathbf{3}$ & Flavonoid & + \\
$\mathbf{4}$ & Tanin & + \\
$\mathbf{5}$ & Terpenoid dan steroid & - \\
\hline Keterangan : $(+)=$ Ada & \\
& $(-)=$ Tidak ada
\end{tabular}

Hasil pengukuran kadar SGOT dan SGPT

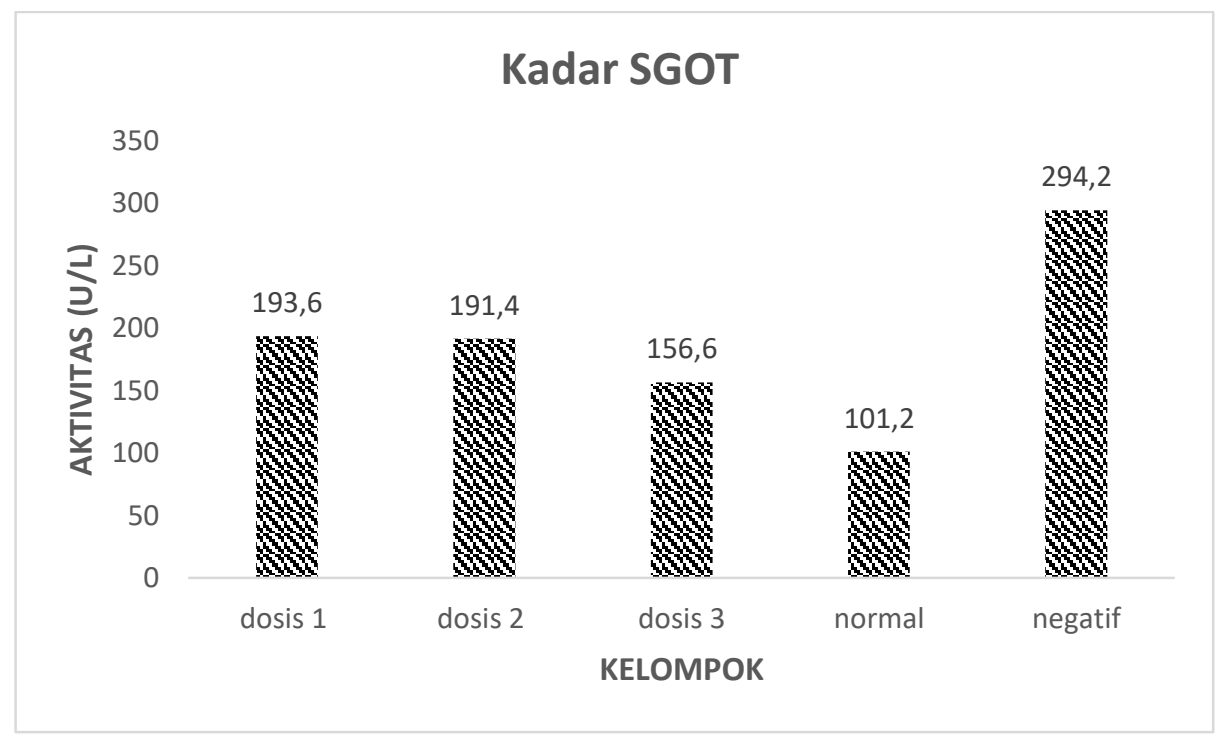

\section{Gambar 1 Grafik Rata-Rata Pengukuran Kadar SGOT}

Hasil pengukuran kadar SGOT menunjukkan data yang didapat terdistribusi normal dan bervariasi homogen $(p \quad>0,05)$. Kemudian dilanjutkan dengan uji ANOVA satu arah dan hasilnya menunjukkan adanya perbedaan $(p<0,05)$. Hasil dari uji 
Tukey menunjukkan terdapat perbedaan

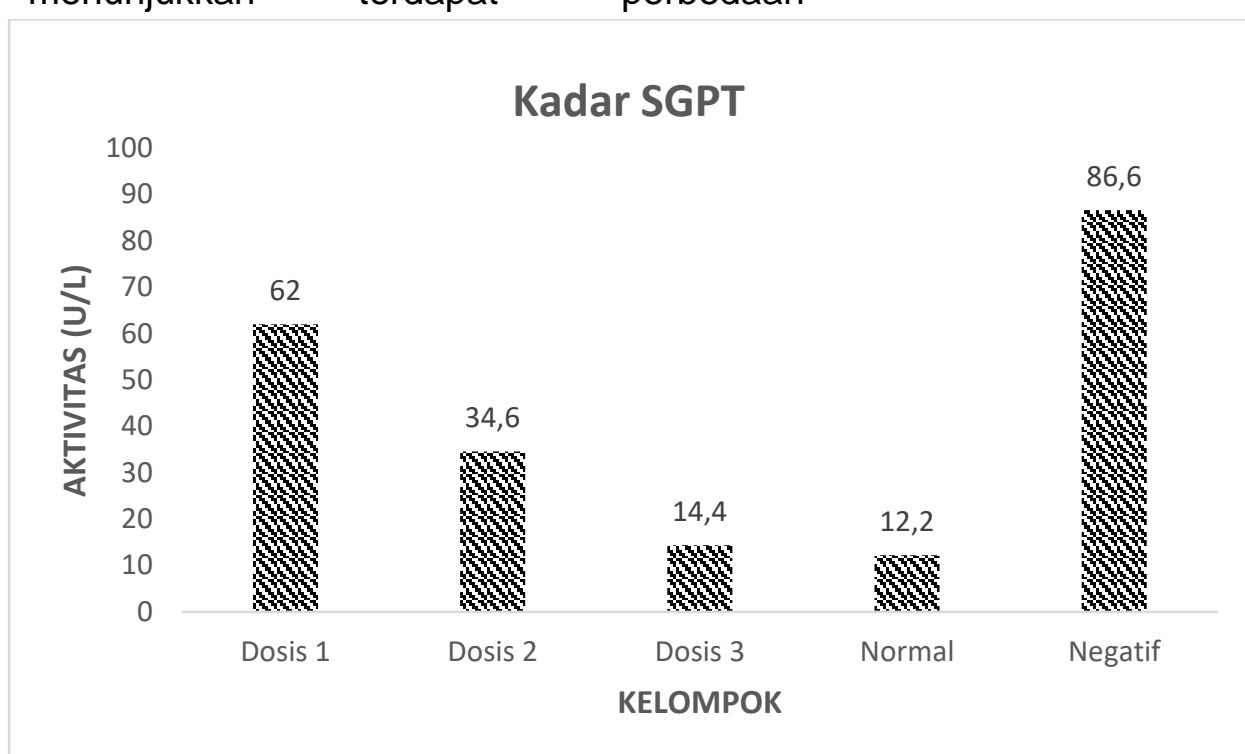

\section{Gambar 2 Grafik Rata-Rata Pengukuran Kadar SGPT}

antara kelompok negatif dengan kontrol normal, dosis 1 , dosis 2 , dan dosis 3 . Pada kelompok negatif terjadi peningkatan kadar SGOT hal ini dikarenakan kelompok negatif merupakan kelompok yang dipapari asap rokok. Nilai rata-rata pada kelompok ini yaitu 294,2. Paparan asap rokok dapat menginduksi kerusakan pada hati karena asap rokok banyak mengandung senyawa radikal bebas dan menyebabkan stress oksidatif sehingga dapat merusak organ seperti hati (Muliartha 2009).

Pada dosis 1, dosis 2, dan dosis 3 mempunyai kemampuan dalam menurunkan kadar SGOT jika dibandingkan dengan kelompok negatif, tetapi masih belum efektif bila dibandingkan dengan kelompok normal (Gambar 1). Hasil pengukuran kadar SGPT menunjukkan data yang didapat terdistribusi normal dan bervariasi homogen $(p \quad>0,05)$. Kemudian dilanjutkan dengan uji ANOVA satu arah dan hasilnya menunjukkan adanya perbedaan $(p<0,05)$. Hasil dari uji Tukey menunjukkan terdapat perbedaan bermakna antara kelompok negatif dengan kontrol normal, dosis 2 , dan dosis 3 tetapi tidak berbeda bermakna dengan dosis 1. Pada kelompok negatif terjadi peningkatan kadar SGPT hal ini dikarenakan kelompok negatif merupakan kelompok yang dipapari asap rokok. Nilai ratarata pada kelompok ini yaitu 86,6. Paparan asap rokok dapat menginduksi kerusakan pada hati karena asap rokok banyak mengandung senyawa radikal bebas dan menyebabkan stress oksidatif sehingga dapat merusak organ seperti hati (Muliartha 2009). Adanya peningkatan kadar SGPT merupakan indikator terjadinya kerusakan pada hati. Hal ini dikarenakan SGPT merupakan enzim yang utama banyak ditemukan pada sel hati yang efektif dalam mendiagnosis kerusakan pada hati (Kee 2007). 
Hasil analisa statistik pada dosis 1 tidak terdapat perbedaan bermakna dengan kelompok negatif. Hal ini menandakan dosis 1 belum mempunyai efek hepatoprotektor karena tidak berbeda bermakna dengan kelompok negatif.Analisa statistik pada dosis 2 menunjukkan terdapat perbedaan bermakna dengan kelompok negative. Hal ini menandakan dosis 2 mempunyai kemampuan dalam menurunkan kadar SGPT tetapi masih belum efektif bila dibandingkan dengan dosis 3 dan kontrol normal (Gambar 2)

Hasil analisa statistik pada dosis 3 menunjukkan terdapat perbedaan bermakna dengan kelompok negatif tetapi tidak berbeda bermakna dengan kontrol normal. Hal ini menandakan dosis 3 mempunyai kemampuan menurunkan kadar SGPT dan mempunyai efek hepatoprotektor yang sebanding dengan kontrol normal

\section{KESIMPULAN}

ekstrak etanol $70 \%$ daun kemuning mempunyai kemampuan menurunkan kadar SGOT dan SGPT. Pada dosis $100 \mathrm{mg} / \mathrm{KgBB}$ ekstrak etanol $70 \%$ daun kemuning mampu menurunkan aktivitas SGOT tetapi tidak pada aktivitas SGPT. Pada dosis $200 \mathrm{mg} / \mathrm{KgBB}$ dan $400 \mathrm{mg} / \mathrm{KgBB}$ ekstrak etanol $70 \%$ daun kemuning memiliki kemampuan menurunkan kadar SGOT dan SGPT sebanding dengan kontrol normal.

\section{DAFTAR PUSTAKA}

Apreliantino, Nur Pradana, et al., 2012. Pengaruh Sidestream Smoke pada Kadar SGPT Tikus wistar
Jantan (Rattus norvegicus). Jember : UNEJ Jurnal. Vol 1:14.

Departemen Kesehatan RI. 2008. Farmakope Herbal Indonesia Edisi I. Departemen Kesehatan RI. Jakarta. HIm. 187

Gautam et al. 2012. Antihyperglycemic and antioxidant potential of murraya paniculata linn. Leaves: a preclinical study.Journal of Pharmacy Research 2012,5(3),1334-1337

Kee, Joyce LeFever. 2007. Pedoman Pemeriksaan Laboratorium \& Diagnostik, Terjemahan : Sari Kurnianingsih. EGC. Jakarta. Hal. 15, 75.

Kementrian Kesehatan Republik Indonesia. Riskesdas. 2010. Penggunaan Rokok. HIm.78

Muliartha, K.I.G., Sriwahyuni, E., Yuliawati. 2009. Pemberian Kombinasi Vitamin $C$ dan $E$ Peroral Memperbaiki Kerusakan Hepar Akibat Paparan Rokok Kretek Sub Kronik. Jurnal Kedokteran Brawijaya. Vol. 26.

Pokorni J, Yanishlieva N, Gordon M. 2001. Antioksidan in food: Pratical Applications, CRC Press, New York. HIm. 2022

Rohman, A., dan S. Riyanto., 2005. Daya Antioksidan Ekstrak Etanol Daun Kemuning (Murraya paniculata (L) Jack) secara in vitro. Majalah Farmasi Indonesia, 16 (3): 136-140 
Sudibyo et al.2013. Aliansi Pengendalian Indonesia. Pengendalian Tembakau Surakarta, University Press.

Unitly, A.J.A., Kusumorini, N., Agungpriyono, $\quad$ S., Satyaningtijas, A.S., Boediono A., 2014. Perubahan Kualitas
Spermatozoa Dan Jumlah SelSel Spermatogenik Tikus Yang Terpapar Asap Rokok. Jurnal Kedokteran Hewan. Vol. 8

Rohman, A., dan S. Riyanto., 2005. Daya Antioksidan Ekstrak Etanol Daun Kemuning (Murraya paniculata (L) Jack) secara in vitro. Majalah Farmasi Indonesia, 16 (3): 136-140 